\title{
Pancasila: Its Emptiness, and What That Means for Social Change in Indonesia
}

\author{
Min Seong Kim \\ \{minseong.kim@outlook.com\}
}

Sanata Dharma University, Indonesia

\begin{abstract}
Owing to the considerable symbolic power it wields as the supposed locus of Indonesian national identity, Pancasila has often been the basis on which particular policies and ideas have been embraced or rejected, and this is a trend that is unlikely to be reversed in the near future. Thus, in considering the viability and efficacy of particular ideas, movements toward social change, and policies that ought to be pursued and implemented in Indonesia in the years to come, it seems imperative to consider how they could be articulated such that they appear as congruent with the values and meaning Pancasila is said to embody. To begin to grasp the values and meaning of Pancasila as they have been understood within post-Reformation Indonesia, this paper proposes to analyze several articles on Pancasila that have appeared on Indonesian academic journals over the past several years. The analysis-which draws from the method of discourse analysis pioneered by Ernesto Laclau and Chantal Mouffe-suggests that Pancasila is an empty signifier, a signifier that has no particular meaning of its own, but precisely for that reason, can be full of meaning. This paper reflects on the political possibilities opened up by Pancasila's emptiness, but also how Pancasila's intertwinement with culture and values perceived to be traditionally Indonesian may imply an irreconcilability with a certain ethos of democratic agonism.
\end{abstract}

Keywords: Pancasila; national identity; democratic agonism; empty signifier

\section{Introduction}

The idea that Indonesia must, in some sense, be guided by Pancasila remains one of the most repeated tropes in Indonesian public discourse. But it might be recalled that forty years ago, around the time the New Order began imposing Pancasila as the sole ideological basis of all social forces, Dwight Y. King (1982), one of the prominent American observers of Indonesia, noted that Pancasila lacks both logical consistency and prescriptions for the future. The remarkably concise "letter" of Pancasila has not changed since. Thus, each appeal to the meaning or values of Pancasila is better understood, even today, as an attempt to construct the very object to which that appeal is ostensibly made. With the aim of examining how the meaning and values of Pancasila are constructed and presented in post-Reformation Indonesia, this paper turns to scholarly articles on Pancasila that have appeared on domestic academic journals within the past few years. The analysis-which draws from the method of discourse 
analysis pioneered by Ernesto Laclau and Chantal Mouffe-suggests that Pancasila is an empty signifier, a signifier that has no particular meaning of its own, but precisely for that reason, can be full of meaning. This paper reflects on the political possibilities opened up by Pancasila's emptiness, but also how Pancasila's intertwinement with culture and values perceived to be traditionally Indonesian may imply an irreconcilability with a certain ethos of democratic agonism.

\section{Results and Discussions}

\subsection{Pancasila's Meaning and Normative Grounds}

In a paper presented at a conference hosted by Oxford University on the theme of human dignity, Dicky Sofjan (2018), a professor of religious studies at Gadjah Mada University, explains that Pancasila, as a "state ideology and political philosophy," has "governed the people of Indonesia" owing to "the veracity of the universal message" it embodies. The said message is contained, it is claimed, in the fact that Pancasila was "unequivocally designed" to "protect and shelter minority groups and potentially vulnerable communities" against "false classification and polarization," which can only breed "unwarranted privileges and discrimination." As an all-inclusive ideology that "knows no othering," Pancasila, Sofjan insists, promotes "a dignified way of life and living for all beings, both humans and nonhumans" (Sofjan 2018:3).

In another article, this time on Pancasila and civic education, the origins of Pancasila is asserted to be the "essence of the nature of Indonesian people who have a high sense of humanity" (Dewantara et al. 2019:403). According to the authors of this article, Pancasila is but a reflection of the Indonesian society that is characterized by "tolerance and other noble traits," such as tepa salira (empathy). A similar assumption about Indonesian society is presupposed in a field study conducted by lecturers and students as part of a university course on Pancasila, which was published in the June 2020 issue of Cakrawala Pendidikan, Indonesia's leading, Scopus-indexed, journal of education. The paper proposes to conduct observational research in three villages in Yogyakarta province that are nicknamed Desa Pancasila, taking note of the "social reality that appears" when local communities are observed "in-depth," in order to "identify the practice of Pancasila values in Indonesian societies" (Kusdarini, Sunarso, and Arpannudin 2020:361).

United in their aim of demonstrating the actuality and relevance of Pancasila in Indonesia today, the three abovementioned papers exhibit the tropes of what might be called "Pancasila Studies," an apparently flourishing area of research in contemporary Indonesian academia. Yet, none of the things that have been said apropos the meaning and value of Pancasila is especially convincing. The first paper by Sofjan relies on a deeply problematic ahistorical conception of Pancasila - by asserting that Pancasila is all-inclusive and perfectly universal, Sofjan dissimulates the historical implementation of Pancasila as an ideological shibboleth, thus a mechanism of exclusion in Indonesia (Abalahin 2005). The essentialism of the second paper is a prime example of the "particularization of the universal" that Immanuel Wallerstein (2006) had warned against in his critique of both orientalism and reactions against orientalism, while the observational study in the third paper is based on a methodological circularity that allows any practice that could reasonably be assessed as displaying communal unity or religious and moral virtues to be counted as an instance of Pancasila's actuality in Indonesian communities. 
It might be argued that the problematic that characterizes all three of the aforementioned papers is an "ideological problematic" in the precise sense that Louis Althusser have given to it: a process of knowledge where "the formulation of a problem is merely the theoretical expression of the conditions which allow a solution" that had been decided in advance outside the process of knowledge by "practical, religious, ethical and political 'interests"” (Althusser and Balibar 1970:52-53). But a treatment of Pancasila within the circularity of an ideological problematic would make it impossible to articulate a convincing response to the question of how it is possible to determine what follows concretely from Pancasila beyond personal proclivities of individual scholars or its many vocal proponents. And if an answer to that question were to remain absent, it would also remain unclear why Pancasila ought to continue to deserve the respect of the Indonesian people at all. But perhaps there is a way of approaching Pancasila that is able to provide an answer to those questions-although, probably, not the kind of answer that would be hoped by treatments of Pancasila a philosophy, Weltanschauung, or the crystallization of the wisdom of the Nusantara.

\subsection{Pancasila as an Empty Signifier}

Amidst the tumultuous years of the mid-twentieth century that had led Clifford Geertz (1973) to remark once that Indonesia gives the impression of a "state manqué," Pancasila was offered as an "inclusive myth" that could act as the basis for Indonesian national identity (O'Shannassy 2010:54). In other words, when considered in formal terms, the problem that Pancasila was designed to address was none other than the fundamental problem of politics as understood within the Hobbesian-Rousseauian tradition, namely, that of creating a political unity out of social diversity. And importantly, what made Pancasila an efficacious solution to this eminent political problem has less to do with the particular moral values or meanings it represented than its intimate connection to a series of projects of nation-building in Indonesia - be they of Soekarno or Soeharto - which promised, in different ways, to deliver something whose presence was felt everywhere in its lack (manque), namely, order.

In presenting itself as the solution to the problem of national unity and social cohesion by representing order as such over and above the "content" of different orders, Pancasila came to assume the role of an empty signifier - a concept elaborated by the Argentinian political theorist Ernesto Laclau, whose theory of hegemony has been described as a radical poststructuralist reformulation of the Hobbesian covenant from which emerges a body politics, or the Rousseauian transmutation of the will of all to the general will (Thomas 2021,330). For Laclau, the "construction of national-popular unity around ideological symbols is the elementary operation of social structuration" (Boucher 2021:374), and an empty signifier performs this operation by serving as the structurally necessary locus of collective identification. A full exposition of the concept of empty signifier and its role in social structuration cannot be given here (see Kim 2018a), but it is not difficult to point to operations of empty signifiers in recent memory. For example, during Donald Trump's presidential campaign, "the American way of life" functioned like an empty signifier (Kim 2018b) Trump's construal of the American way of life as something that needed to be protected from threats allegedly posed by the intrusive presence of an "other," such as immigrants from Asia and Latin America, was able to mobilize a certain collective identity, precisely to the extent what it really meant was left sufficiently ambiguous so as to allow different people to recognize in that expression whichever things they wished to preserve.

An empty signifier, therefore, is empty in as much as it has no determinate signified of its own. But for precisely that reason, it can be full of meaning. A cursory glance at the 
discussions around Pancasila in the Indonesian public discourse of the past couple of years suffices to show how Pancasila has been attached to various topics of the day. In a newspaper op-ed, the rector of a major public university in Central Java contended that universities must serve as "bastions of Pancasila" wherein Pancasila will be "translated into a theory of praxis for millennials" (Koran Sindo, May 31, 2021). Megawati argued in an English-language article-published by the Defence University of Indonesia, from which she received an honorary doctorate in 2021 - that Pancasila is the "solution" to a "new phenomenon that endangers humanity," namely, "post-truth" (Soekarnoputri 2021:132). Amidst the Covid-19 pandemic, one scholar had even argued that the five principle of Pancasila could be used to "combat" the pandemic (Setiawan 2020). Not very much of these implications supposedly drawn from Pancasila can actually be traced to anything innate to Pancasila, which, in any case, was never intended to be a theoretical system from which concrete prescriptions could be derived. It might be said, instead, that Pancasila, as a signifier, is without depth — but that for exactly this reason, it has functioned as the surface of inscription of various ideals, values, and social and political projects.

This is to say that the meaning and value imputed to Pancasila have been subjected to drastic reformulations. It is not uncommon to hear nowadays claims that human rights, once assumed by Indonesia's leaders and ideologues as alien to traditional culture (Kymlicka 1998), are perfectly compatible with Pancasila. But this compatibility is surely a new articulation of Pancasila whose purpose is to make it reflect the social and political changes of the postSoeharto era. Tracing the compatibility of Pancasila with human rights to some quality that was intrinsic to Pancasila from the beginning would in fact risk downplaying the historical conditions of its emergence, such as the fact that the early promulgators of Pancasila including Soekarno himself, or the architect of the 1945 Constitution, Soepomo, had little appreciation for the very idea of human rights (Ulum and Hamida 2018). In the end, it can plausibly be said that acting as a "receptacle" of the clamor of new ideas in post-Soeharto society is what keeps Pancasila relevant today. After all, there would be no reason why Pancasila ought to continue to be respected by the people of Indonesia as something central to their identity if Pancasila could not be the means by which all kinds of popular aspirations are expressed.

\subsection{Democratic ethos and Pancasila}

As long as Pancasila, qua an empty signifier, functions as a potent symbol of Indonesia's national identity, presenting a progressive, socially transformative agenda as a deepening of Pancasila may continue to be one of the most effective political strategies in the country. It is not impossible to imagine a political practice in Indonesia that collectivizes a variety of progressive projects in the name of Pancasila. And when the plurality of projects articulated under Pancasila are extensive enough, nothing would prevent it from calling it - to borrow the expression used by Yudi Latif (2015) - a "Pancasila Revolution." In fact, the production and utilization of empty signifiers are at the center of the strategy of "left populism" toward farreaching social change defended by Laclau (2005) and his long-time collaborator Chantal Mouffe (2018).

Yet, it might be asked whether, despite the emptiness of Pancasila, there is a limit to social change that could be pursued in its name. For, Pancasila is no exception to Laclau's poststructuralist stipulation that a signifier, even empty ones, can never be completely expunged of its own particularity. It is very much possible that the letter of the first principle that reads as a monotheistic prescription might continue to be used in arguments to exclude certain identities - such as those who adhere to indigenous polytheistic religions and those who are 
atheists - from articulations of Indonesian national identity. Moreover, it should not be forgotten that every social and political practice takes place on an uneven terrain of sedimented meanings and power differentials, which has a bearing on the popular acceptability of certain projects. Laclau thus speaks of the possibility of the "imprisonment" of an empty signifier, a limitation imposed by the historical circumstances on the particular content it is capable of representing. One such limitation worth considering is how Pancasila, owing to the theories of the state and nation that had influenced its creator, has long been associated with a political ethos supposedly specific to Indonesia.

In the early years of the Soviet Union, there were ideologues who claimed that a communist state needs a "proletarian physics" purified of the bourgeois, idealist tendencies of mainstream physics (Bell 1960:397). This idea never gained traction-most Soviet physicists dismissed it as nonsense. But the idea that there are culture-specific versions of democracy has proven to be far more resilient and popular, including among political theorists. Thus, one finds in Indonesian history an idealized vision of village life as co-operative, tolerant, and harmonious serving as the basis of a popular understanding of its "national character (sifat bangsa)." Such a vision-Soekarno's interest in which was a result of his encounter with the thoughts of Ernest Renan and Otto Bauer - continues to shape the understanding of the kind of political system supposedly suited to Indonesia. Thus, while the resurgence of the expression "Pancasila Democracy" in recent years is probably (and hopefully) not a reactionary call to return to the Soeharto era "family state," it is not clear what the ethos evoked by today's vocal proponents of Pancasila could be, other than that which underpins supposedly traditional culture of governance, such as, mufakat and musyawarah, consensus and consultation.

Yet, it might be asked whether the emphasis on a specifically Indonesian implementation of democracy, even among "liberal" proponents of Pancasila, has hindered a sustained exploration of the implications of the various radicalizations of the understanding of democracy from outside Indonesia. A particularly unfortunate missed encounter was with agonistic approaches in democratic theory. One of the key objectives for proponent of agonism has been that of overcoming the limitations of consensual or deliberative paradigm in realizing a pluralist society (see, for example, Mouffe 1999), an objective that would seem to be especially pertinent for a country whose national motto, Bhinneka Tunggal Ika, has always been more a statement of a problem than a description of social reality.

But if agonism merits interest for its critique of the deliberative paradigm in the name of pluralism, agonism also represents a challenge for the widespread idea that Pancasila values are somehow able to foster, or at least are compatible with, pluralism and democracy. This is because in the agonistic approach, democracy requires the abandonment as ultimate political ends of consensus and social harmony. In this vein, the French political philosopher Jacques Rancière $(1998,2009)$ asserts that democracy, in one of its dimensions that is irreducible to procedures and institutions, is a subversive practice of dissensus by which established norms - that is, consensus - are put to the test. For Laclau and Chantal Mouffe, co-authors of Hegemony and Socialist Strategy (1985) in which the earliest articulation of a "radical democratic imaginary" is found, a truly pluralistic democracy presupposes the absence of ultimate foundations of any social order, and that every social order is temporary, fragile, and incomplete. For, it is precisely the failure of the order to be identical to itself in perfect harmony that it could be challenged and transformed through political struggles and rearticulations of new social imaginaries. If the ethos of agonistic democracy-hinted by its etymology - appears incompatible with that of the traditional Indonesian culture that Pancasila is regarded by many as embodying, then it is perhaps time to reexamine the democratic potentials of Pancasila as it is commonly understood in Indonesia today. 


\section{Conclusion}

If Pancasila is an efficacious symbol able to support the mobilization of a large section of the national constituency, it would be wise for any projects of social change within Indonesia to present themselves as compatible with Pancasila or as furthering Pancasila values. However, while particular projects might be pursued in the name of Pancasila, even if mainly for pragmatic reasons, Pancasila's still powerful ties to traditional communitarian values is likely to pose challenges for projects that are radically pluralist in orientation and may be based on an ethos incompatible with the one with which Pancasila has long been associated.

\section{References}

[1] Abalahin, Andrew J. 2005. "A Sixth Religion?: Confucianism And The Negotiation Of Indonesian-Chinese Identity Under The Pancasila State." in Spirited Politics: Religion and Public Life in Contemporary Southeast Asia, ed. A. C. Willford and K. M. George. Ithaca: Cornell Southeast Asia Program.

[2] Althusser, Louis, and Étienne Balibar. 1970. Reading Capital. London: New Left Books.

[3] Bell, Daniel. 1960. The End of Ideology: On the Exhaustion of Political Ideas in the Fifties : With "The Resumption of History in the New Century." Cambridge: Harvard University Press.

[4] Boucher, Geoff. 2021. "Ernesto Laclau (1935-2014) and Chantal Mouffe (1943- )." in Routledge Handbook of Marxism and Post-Marxism, ed. A. Callinicos, S. Kouvelakis, and L. Pradella. New York: Routledge.

[5] Dewantara, Jagad Aditya, Ilham Fajar Suhendar, Rum Rosyid, and Thomy Sastra Atmaja. 2019. "Pancasila as Ideology and Characteristics Civic Education in Indonesia." International Journal for Educational and Vocational Studies 1(5):400-405. doi: 10.29103/ijevs.v1i5.1617.

[6] Geertz, Clifford. 1973. The Interpretation of Cultures. ed. C. Holt. New York: Basic Books.

[7] Kim, Min Seong. 2018a. "Processes of Social Change in the Works of Badiou and Laclau." PhD, University of Essex, Colchester, UK.

[8] Kim, Min Seong. 2018b. "The Courage to Have Courage." Soundings: An Interdisciplinary Journal 101(1):30-40. doi: https://doi.org/10.5325/soundings.101.1.0030.

[9] Kusdarini, Eny, Sunarso Sunarso, and Iqbal Arpannudin. 2020. “The Implementation of Pancasila Education Through Field Work Learning Model.” Jurnal Cakrawala Pendidikan 39(2):359-69. doi: 10.21831/cp.v39i2.31412.

[10] Kymlicka, Will. 1998. "Human Rights and Ethnocultural Justice." Review of Constitutional Studies 4(2):213-38.

[11] Laclau, Ernesto. 2005. On Populist Reason. London: Verso.

[12] Laclau, Ernesto, and Chantal Mouffe. 1985. Hegemony and Socialist Strategy: Towards a Radical Democratic Politics. London: Verso.

[13] Latif, Yudi. 2015. Revolusi Pancasila. Bandung: Mizan.

[14] Mouffe, Chantal. 1999. "Deliberative Democracy or Agonistic Pluralism?" Social Research 66(3):745-58. 
[15] Mouffe, Chantal. 2018. For a Left Populism. London: Verso.

[16] O'Shannassy, Michael. 2010. “(Re)Imagining Community - Pancasila and National Identity in Contemporary Indonesia." in Pancasila's Contemporary Appeal: Relegitimizing Indonesia's Founding Ethos, ed. F. Dhont. Yogyakarta: Sanata Dharma University Press.

[17] Rancière, Jacques. 1998. Disagreement: Politics and Philosophy. Minneapolis: University of Minnesota Press.

[18] Rancière, Jacques. 2009. Hatred of Democracy. London: Verso.

[19] Setiawan, Kristina Untari. 2020. "Mengoptimalkan Nilai-Nilai Pancasila Selama dan Sesudah Pandemi Covid-19." Diligentia: Journal of Theology and Christian Education 2(3):78-89. doi: 10.19166/dil.v2i3.2421.

[20] Soekarnoputri, Megawati. 2021. "The Establishment of Pancasila as the Grounding Principles of Indonesia." Jurnal Pertahanan 7(1):122-36. doi: 10.33172/jp.v7i1.1206.

[21] Sofjan, Dicky. 2018. "Pancasila and the Dignity of Humankind." International Journal of Interreligious and Intercultural Studies 1(1):1-3. doi: 10.32795/ijiis.vol1.iss1.2018.82.

[22] Thomas, Peter D. 2021. "After (Post) Hegemony." Contemporary Political Theory 20(2):318-40. doi: 10.1057/s41296-020-00409-1.

[23] Ulum, Muhammad Bahrul, and Nilna Aliyan Hamida. 2018. "Revisiting Liberal Democracy and Asian Values in Contemporary Indonesia." Constitutional Review 4(1):111-30. doi: 10.31078/consrev415.

[24] Wallerstein, Immanuel. 2006. European Universalism: The Rhetoric of Power. New York: New Press. 